\title{
Effect of land use on pollution status and risk of fish endocrine disruption in small farmland ponds
}

\author{
Syaghalirwa N. M. Mandiki • Virginie Gillardin • Koen Martens • \\ Dirk Ercken • Els De Roeck • Tom De Bie • Steven A. S. Declerck • \\ Luc De Meester - Catherine Brasseur - Edwige Van der Heiden • \\ Marie-Louise Schippo • Patrick Kestemont
}

Received: 15 November 2012/Accepted: 26 July 2013/Published online: 23 August 2013

(C) Springer Science+Business Media Dordrecht 2013

\begin{abstract}
To study whether the intensity of agricultural activities affects pesticides loads in pond environment, a large number of Belgian farmland ponds were surveyed in spring 2004. Temporal distribution of pollutants was also investigated over restricted survey ponds sampled three times round year 2007. Sedentary pond Prussian carp juveniles were also captured to determine their brain aromatase activity (AA) and plasma vitellogenin (VTG) levels. Heavy metal distribution was also examined in various pond matrices. Amongst the pesticides analysed, only herbicides were detected. Contamination of pond water by atrazine was frequently observed during spring 2004, while isoproturon and glyphosate were detected round year 2007. Levels of herbicides were inversely related to the distance of ponds to crop field, and values peaked in April or October. Absence of
\end{abstract}

Guest editors: R. Céréghino, D. Boix, H.-M. Cauchie,

K. Martens \& B. Oertli / Understanding the role of ponds in a changing world

S. N. M. Mandiki $(\varangle) \cdot$ V. Gillardin · P. Kestemont University of Namur, URBE-NARILIS, 61 Rue de

Bruxelles, 5000 Namur, Belgium

e-mail: Robert.Mandiki@fundp.ac.be

K. Martens · D. Ercken · E. De Roeck

Royal Belgian Institute of Natural Sciences, Vautierstraat

29, 1000 Brussels, Belgium

T. De Bie - S. A. S. Declerck · L. De Meester

32, 3000 Leuven, Belgium endocrine disruptors in pond water was confirmed by lack of modulation in VTG and AA in male fish. Heavy metals were present in all the pond matrices, but overall contamination levels were low. The results demonstrated that Belgian ponds were mainly contaminated by herbicides and that pond sedentary fish were not affected by endocrine disruptors. They also demonstrated a marked effect of land-use intensity on herbicide pollution which can be mitigated by an adjustment of the buffer zones.

Keywords Pollution · Ponds · Prussian carp · Endocrine disruption · Land-use intensity .

Herbicides $\cdot$ Heavy metals

\section{Introduction}

Pools and small ponds have in addition to their aesthetic and agricultural values a high conservation value (Scheffer et al. 2006). Their biotopes are

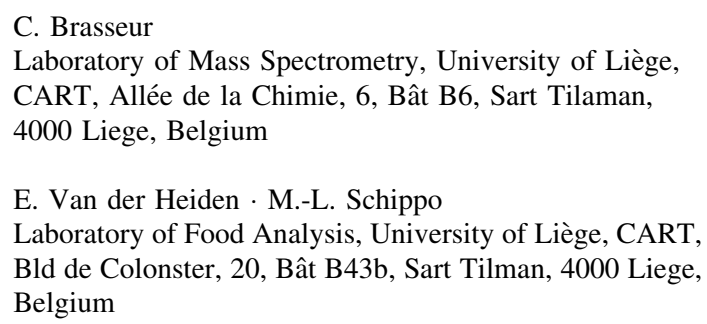


characterized by heterogeneous communities of aquatic organisms, and they often contain rare or unique species (Williams et al., 2003; Wood et al., 2003; Nicolet et al., 2004). Several studies have reported the contribution of small ponds to regional diversity to be higher than that of other freshwater ecosystems such as lakes and rivers (Davies et al., 2008; Williams et al., 2008). In predominantly agricultural areas, small water bodies offer a special refuge to many aquatic biotas and thus contribute to mitigate the decline in overall biodiversity.

Because of the limited water exchange compared to large water bodies, various pollutants can accumulate in pond environments, which may impact the aquatic organisms inhabiting the ponds. The effects of landuse intensity on pesticide accumulation in the pond environment, and its effects on pond biota, are, however, poorly documented. Despite the ban of atrazine in the EU, this herbicide is still used in other countries and, because of its rather resistant nature, it is still often detected in sediments and surface waters (Wu et al., 2009; Sun et al., 2010). Herbicides, such as diuron, isoproturon and glyphosate herbicides, are nowadays widely used worldwide, and their accumulation has been reported in pond water (Greulich et al., 2002; Howe et al., 2004; Bonnet et al., 2007; Rohr et al., 2008). Besides their direct inhibitory actions on trophic resources, such as aquatic plants and insects, herbicide molecules have various deleterious effects on aquatic organisms. While data on the potential hormonal effects of atrazine are still controversial in fish (Spanò et al., 2004; Nadzialek et al., 2008; Tillitt et al., 2010), numerous studies demonstrated that this pesticide, at environmentally relevant concentrations, has marked endocrine disrupting effects that affect the central nervous and immune system of frogs and salamanders (Sparling et al., 2001; Forson \& Storfer, 2006; Kloas et al., 2009; Lasserre et al., 2009; Hayes et al., 2010a). High concentrations of glyphosate herbicides and the associated surfactants have also various detrimental effects on amphibian tadpoles, such as the disturbance in the metamorphosis process, tail damages and gonad abnormalities (Howe et al., 2004; Barni et al., 2007; Brausch \& Smith, 2007; Dinehart et al., 2009). It has also been shown that combinations of chemicals, including atrazine, diuron, isoproturon and their breakdown products, at environmentally relevant concentrations are more toxic to fish and amphibians than the parent compounds in isolation (Spanò et al., 2004; Fatima et al., 2007; Bonnet et al., 2007). Some pesticides that are already known to be resistant to degradation might be accumulated in small pond environments, as there is no dilution or flushing effect. Insecticides or industrial compounds such as aldrin or nonylphenol can induce sex reversal in fish and amphibians by altering various neuroendocrine pathways including those controlling reproductive functions. They may induce an increase in the expression and activity of P450 aromatase, leading to an increase in oestrogen production that subsequently induces VTG accumulation in the liver and bloodstream (Folmar et al., 2001; Jobling \& Tyler, 2006; Hayes et al., 2006; Wingfield \& Mukai, 2009; Nadzialek et al., 2011). Production of VTG induced by an increase in P450 AA in males has been used as a reliable biomarker to assess the occurrence of endocrine disruption (Folmar et al., 2001; Desforges et al., 2010; Nadzialek et al., 2011).

Presence of PAHs may also be suspected in the different pond matrices since they are ubiquitous in the environment due to mostly industrial activities but also due to other anthropogenic sources. PAHs are known to be strongly persistent with good dispersal properties (Guo et al., 2011). Apart from their known carcinogenic, mutagenic and endocrine disrupting properties (Brasseur et al., 2007; Guo et al., 2011; Rhind et al., 2011), PAHs have been shown to alter both the specific and non-specific immune system as well as the health status of different fish and other animals living in aquatic environment (Lampi et al., 2006; Reynaud \& Deschaux, 2006; Gillardin et al., 2009; Milinkovitch et al., 2011; Danion et al., 2011).

Amongst the persistent pollutants, accumulation of heavy metals is frequently assessed for monitoring the health status of water bodies (Maas et al., 2010; Rimondi et al., 2012). Apart from geochemical processes, increase in heavy metals in pond environments may be caused by various sources, such as industrial and traffic emissions as well as run-off from habitations, especially in urbanized areas. Although it has been demonstrated that metal pollution loads are markedly higher in urbanized industrial landscapes than in agricultural areas (Imperato et al., 2003), agricultural operations such as sewage sludge or fertilizer use may increase metal contamination in soils, especially of cadmium $(\mathrm{Cd})$, copper $(\mathrm{Cu})$ and zinc (Zn) (Nicholson et al., 2003; Maas et al., 2010). Intensification of agricultural activities and other 
human activities may increase the run-off release of heavy metals in pond environments, but the effect of land-use intensity on heavy metal pollution is not yet quantified. Accumulation of heavy metals in pond matrices may induce detrimental effects on aquatic organisms, for instance by altering their physiological and defence ability (Desouky, 2006; Reynders et al., 2008; Ng et al., 2011; Rimondi et al., 2012).

The objective of our study was to evaluate pesticide and heavy metal pollution status as well as risk of fish endocrine disruption in Belgian small farmland ponds in relation to land-use level. To achieve this objective, (1) we investigated the effect of land-use level on herbicide loads in pond water as well as on heavy metal concentrations in various pond matrices during two large surveys covering the entire Belgian territory; (2) we verified whether there is seasonal variation in pesticide pollution in pond water, focussing on various problematic pollutants; and (3) we assessed a number of indicators of reproductive endocrine disruption in Prussian carp (Carassius auratus gibelio) juveniles resident in ponds located in intensive or extensive agricultural areas.

\section{Materials and methods}

Seasonal changes in pesticide loads in pond water

\section{Survey designs and analysed pesticides}

Two surveys were conducted in order to investigate whether changes in pesticide pollution in pond water vary with land-use intensity. In the first survey conducted during May-June 2004, 126 ponds across almost the entire territory of Belgium (Fig. 1a) were sampled for water. For the selection of the investigated ponds, the dominant land-use type in the immediate neighbourhood of the ponds was the main criterion (see also Declerck et al., 2006). We tried as much as possible to uncouple land use and geographical position. To do so, we first selected forty-two geographically spread clusters such that each cluster contained several ponds that were located within a circular area of approximately $20 \mathrm{~km}^{2}$ (Declerck et al., 2006). Within each cluster, we then selected three ponds that correspond to a gradient in agricultural land-use intensity, ranging from intensive agricultural activities (mostly cropland; "intensive ponds"), over intermediate agricultural land use (dominated by pastures; "extensive ponds") to more pristine ("natural", mostly located in protected nature areas). Crop presence was noticed around the majority of ponds: cropland was within a radius of 10 or $20 \mathrm{~m}$ for intensive or extensive ponds, while for natural ponds, no crop activities was present or cropland was observed within a radius $>100 \mathrm{~m}$. Other details concerning the investigated sites have been previously described by Declerck et al. (2006). Pesticide analyses focussed mostly on herbicides (atrazine, simazine, propazine, terbuthylazine, triazine metabolites, diuron and isoproturon) but also on insecticides, namely endosulfan and lindane.

A second survey was carried out in 2007. This survey was more limited in number of ponds but involved three samples to cover temporal dynamics, involved a broader range of pesticides, and also included industrial pollutants. Fifteen small ponds were selected covering the three land-use categories (Fig. 1b); these ponds were a subset of the ponds sampled in 2004. Water was sampled three times (April, July and October 2007) with an interval time long enough to cover the dissipation time of various pesticide molecules in water conditions (Mouvet et al., 1997; Sørensen et al., 2003; Tissier et al., 2005). The pollutants that were quantified were as follows: (1) herbicides: atrazine, simazine, propazine, terbuthylazine, triazine metabolites, diuron isoproturon, glyphosate and aminomethyl-phosphonic acid (AMPA); (2) insecticides: aldrine, chlorfenvinphos, $\alpha$-endosulfan and dicofol; (3) industrial compounds: octylphenol, nonylphenol, aldrine and four polycyclic aromatic hydrocarbons (PAHs: benzo(b)fluoranthene, benzo(k)fluoranthene, benzo(a)pyrene) and benzo(ghi)perylene). A summary of the number of investigated ponds and types of analysed pesticides is presented in Table 1.

\section{Water sampling and pesticide analyses}

For analyses of the targeted pesticides, a pool of 21 water was taken at eight randomly selected sampling stations in each pond ( 4 in the middle of the pond and 4 close to the edge). Just after sampling, water was filtered over a $20-\mu \mathrm{m}$ mesh screen in order to remove large organic particles, and then, one litre of the water sample was kept at $4^{\circ} \mathrm{C}$. In the laboratory, the water samples were stored at $-20^{\circ} \mathrm{C}$. Before solid phase extraction (SPE) of pesticides, the water samples were 
Fig. 1 a Map of Belgium showing the locations of the 42 investigated clusters (circular symbols). Within a cluster, three small ponds were selected along a maximal gradient of surrounding agricultural land-use intensity, ranging from relatively natural area ("ponds in natural areas"), pastures with low cattle density ("extensive land-use ponds") to areas with intensive agriculture, especially cropland ("intensive land-use ponds"). b Locations of the 15 small ponds selected in the Northern (Flanders) and Southern (Wallonia) regions of Belgium in areas of intensive or extensive land use or in natural reserves. The ponds were selected amongst the 126 ponds sampled during spring 2004 using the same gradient of land-use intensity

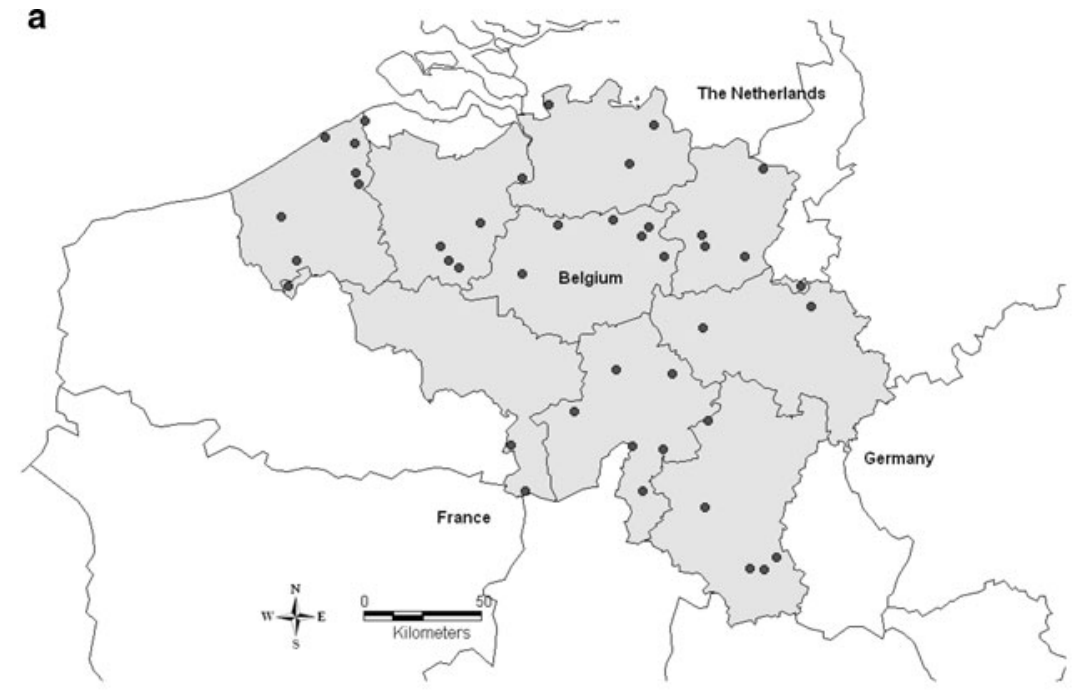

b

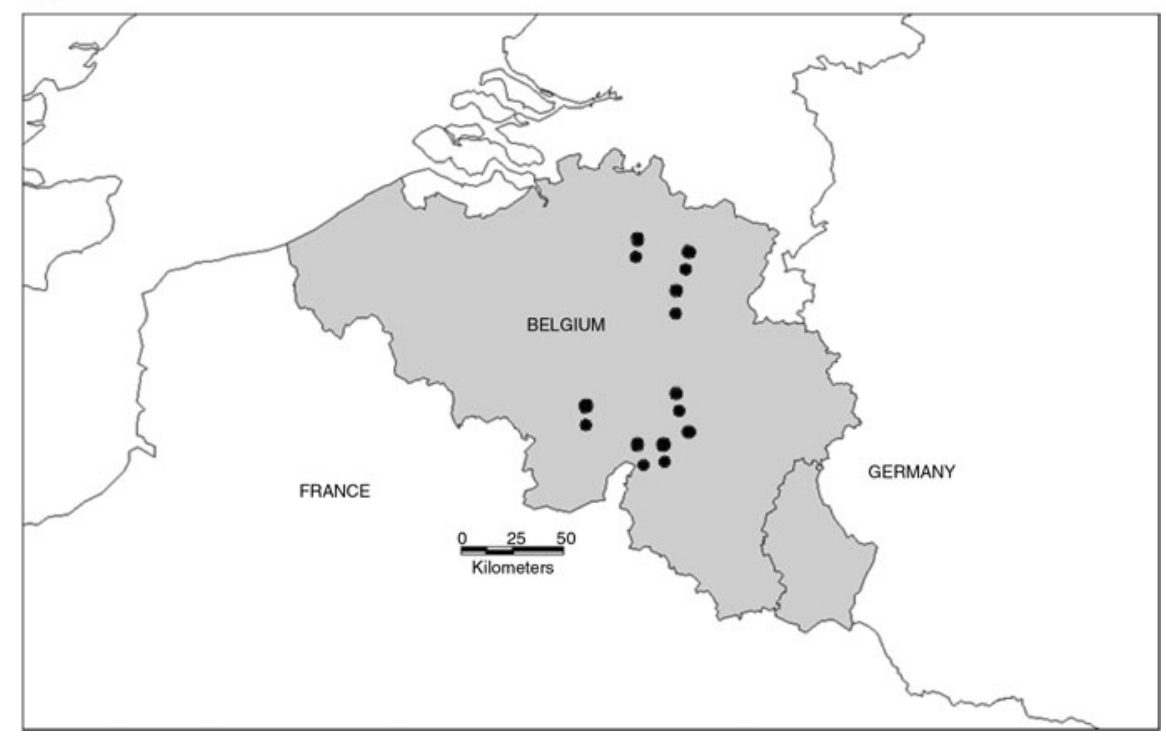

filtered over a $10-\mu \mathrm{m}$ Whatman screen to eliminate remaining large organic particles and then successively over 2.0- and 0.6- $\mu \mathrm{m}$ Millipore screens. $\mathrm{C}_{18}$ cartridges (6-ml Oasis column, Waters) were cleanconditioned by methanol and MEQ water before samples were loaded at a rate of $6 \mathrm{ml} / \mathrm{min}$ and eluted by acetonitrile. After SPE, the eluted samples were stored at $-20^{\circ} \mathrm{C}$ until HPLC (only for triazines), or GC-MS analyses were applied as previously described in Nadzialek et al. (2010). Before injection, $1 \mathrm{ml}$ of the eluted sample was filtered $(0.2 \mu \mathrm{m})$, and this filter was rinsed with $1 \mathrm{ml}$ acetonitrile before solvent evaporation under $\mathrm{N}_{2}$. The dry residue was suspended in $90 \mu \mathrm{l}$ of hexane and $10 \mu \mathrm{l}$ of a solution (in hexane) of [ $\left.{ }^{2} \mathrm{H}_{12}\right]$ chrysene (200 pg injected), used as internal standard. The detection limit was $10 \mathrm{ppb}$ for all pesticides. Glyphosate and its metabolite AMPA were quantified in water by a LC-MS method. After SPE clean-up as for other pesticides, samples were derivatized with 9-fluorenylmethyl chloroformate following the method described by Koeber et al. (2001) and Ibáñez et al. (2006). Then, eluted concentrated samples were analysed with an Alliance 2,690 liquid chromatography system and a Micromass 
Table 1 Summary of pesticide surveys covering almost the entire Belgium territory (spring 2004) or the main pesticide pulverizations periods (April, July and October) over 2007

\begin{tabular}{llc}
\hline & $\begin{array}{l}\text { Once sampling } \\
\text { over Spring 2004 }\end{array}$ & $\begin{array}{l}\text { Three-month } \\
\text { sampling over 2007 }\end{array}$ \\
\hline $\begin{array}{l}\text { Number of ponds } \\
\begin{array}{l}\text { Pesticide types: } \\
\text { Herbicides }\end{array}\end{array}$ & 15 \\
& $\begin{array}{c}\text { atrazine, simazine, propazine, } \\
\text { terbuthylazine, triazine } \\
\text { metabolites, diuron, isoproturon }\end{array}$ & $\begin{array}{c}\text { atrazine, simazine, propazine, terbuthylazine, } \\
\text { triazine metabolites, diuron, isoproturon, } \\
\text { glyphosate, aminomethyl-phosphonic } \\
\text { acid (AMPA) }\end{array}$ \\
$\begin{array}{l}\text { Insecticides } \\
\text { Industrial compounds }\end{array}$ & $\begin{array}{l}\text { aldrine, chlorfenvinphos, endosulfan, dicofol } \\
\text { octylphenol, nonylphenol, } 4 \text { polycyclic } \\
\text { aromatic hydrocarbons (PAHs: } \\
\text { benzo(b)fluoranthene, benzo(k)fluoranthene, } \\
\text { benzo(a)pyrene) and benzo(ghi)perylene) }\end{array}$ \\
\hline
\end{tabular}

Quattro Ultima Platinum triple quadrupole mass spectrometer (Waters/Micromass, Manchester, U.K.). The quantification limit of both glyphosate and AMPA was $10 \mathrm{ppb}$.

\section{Reproductive disruption in fish}

The objective of this part of our research was to evaluate the risk of reproductive disruption in sedentary pond fish. Prussian carp (Carassius auratus gibelio, a goldfish subspecies) was selected as resident fish sentinel because it was one of the most abundant fish species present in the ponds (results not shown). Six intensive or extensive ponds of the 15 ponds already surveyed for pesticide loads in 2004 and 2007 were selected. Ten juveniles ( 5 males and 5 females) (35-65 g) from each pond were captured in 2008 and 2009, weighed and blood sampled for plasma to determine plasma VTG levels. Then, fish were dissected for gonad and brain samples to estimate the gonadosomatic index (GSI, $100 *$ gonad weight/ body weight) and the brain aromatase activity.

Blood samples were taken from the caudal vessel using heparinized syringes. The samples were centrifuged for $20 \mathrm{~min}$ at $4,500 \mathrm{rpm}$, and the plasma was collected and stored at $-80^{\circ} \mathrm{C}$ until assayed for VTG. Plasma concentrations of VTG were quantified by ELISA, using a carp commercial VTG ELISA kit (SPID $\mathrm{BIO}$, France) with a detection limit of $10 \mathrm{ng} / \mathrm{ml}$ and an intra- and inter-coefficient of variation of 4.85 and $5.85 \%$, respectively. Brain aromatase activity was quantified by a radioimmunoassay enzymatic method described by Noaksson et al. (2001) and Gonzales \& Piferrer (2003) (see also Mandiki et al., 2005). Briefly, the brain homogenate sample was mixed with a generating solution (NAA) containing $1 \mathrm{mM} \beta \mathrm{NADPH}$ (Sigma N-0505, Steinheim, Germany), 25nM androst4-ene-3,17-dione-[1 $\left.\beta-\mathrm{H}^{3}\right]$ (NEN, Boston, USA) and $275 \mathrm{nM}$ androst-4-ene-3,17-dione (Sigma, Steinheim, Germany). More specifically, $100 \mu \mathrm{l}$ of tissue homogenate, representing $10 \mathrm{mg}$ of brain tissue, was mixed with $150 \mu \mathrm{l}$ of $300 \mathrm{nM}$ NAA and $50 \mu \mathrm{l}$ buffer solution and incubated for $60 \mathrm{~min}$ in a water bath at $30^{\circ} \mathrm{C}$ with gentle shaking. A control tissue homogenate mixed with a substrate without NADPH to prevent aromatase activity was co-incubated simultaneously. The enzymatic reaction was stopped by the addition of trichloroacetic acid (TCA, 10\%), and then, samples were centrifuged (8,000 rpm, $10 \mathrm{~min})$. The concentrations of proteins in the pellets were determined by the Lowry method. The supernatant was extracted with chloroform

Table 2 Summary of the number of ponds and pond matrices tested for heavy metals $(\mathrm{Cd}, \mathrm{Sn}, \mathrm{Zn}, \mathrm{Cu}, \mathrm{Pb}$ and $\mathrm{Hg}$ ) during summer 2003 and spring 2004

\begin{tabular}{llc}
\hline & Summer 2003 & Spring 2004 \\
\hline Water & 99 & 126 \\
Suspended solids & 99 & - \\
Sediment & - & 68 \\
Snails & 14 & 34 \\
\hline
\end{tabular}

No sampling 
for the aqueous phase, which was mixed with dextrancoated $(5 \%)$ charcoal $(0.5 \%)$ and quantified using a liquid scintillation counter. The intra- and inter-coefficients of variation of the assays were 5.55 and $6.85 \%$, respectively.

\section{Heavy metal distribution}

During summer 2003 or spring 2004, we sampled different pond matrices (water, suspended solids, sediment and snails) to analyse the following heavy metals: cadmium-Cd, tin-Sn, zinc-Zn, copper-Cu, lead$\mathrm{Pb}$ and mercury- $\mathrm{Hg}$ (the latter only in water samples of 2004). The number of ponds and pond matrices investigated is summarized in Table 2. For each pond, water was sampled at 8 locations as in pesticides design using a tube sample integrating the entire water column. The water taken at the different locations was pooled and filtered over $2 \mathrm{~mm}$ to remove larger

Fig. 2 a-b: Atrazine occurrence (a) and concentrations (b) in water sampled during spring 2004 in ponds located in relatively natural areas, areas with extensive and areas with intensive agricultural land use. Atrazine

contaminations were higher $(P<0.05)$ in intensive landuse ponds than in extensive land-use ponds or ponds in natural ponds. $n=$ number of ponds in which atrazine was detected organic and other materials. Then, 2 litres of water of each pond was brought to the laboratory in a cooling box $\left(4^{\circ} \mathrm{C}\right)$. Upon arrival in the laboratory, the water sample was filtered through a $125-\mu \mathrm{m}$ Teflon mesh screen to remove large organic particles and then over a $1.2-\mu \mathrm{m}$ filter. These filters were used for analysing heavy metal concentrations in suspended solids, whereas $10 \mathrm{ml}$ of the filtrate was used to quantify heavy metal concentrations in the water. Filters were cleaned with $\mathrm{HNO}_{3} 10 \%$ prior to use. For $\mathrm{Hg}$ analyses in water samples, acid-cleaned $(1 \% \mathrm{HNO})$ glass bottles were used and filtration was performed as soon as possible with appropriate filtration equipment pretreated for trace metal analysis to avoid contamination. Sediment samples were taken from the upper sediment layer $(0-3 \mathrm{~cm})$ at eight sampling stations in each pond ( 4 in the middle of the pond and 4 close to the edge). They were placed in plastic bottles and dried at $60^{\circ} \mathrm{C}$ during $48 \mathrm{~h}$. Before analyses, they were calcinated at
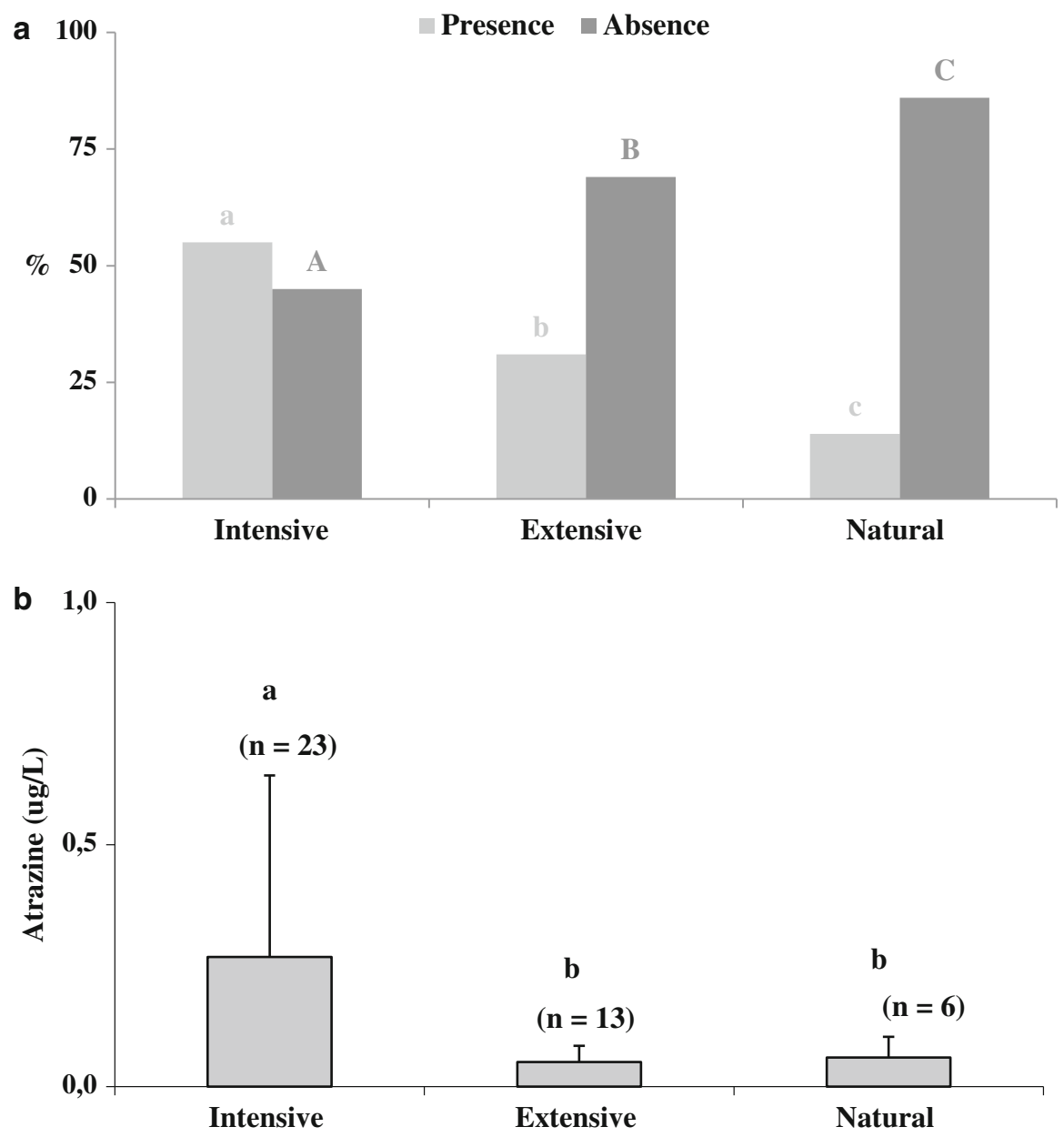
$650^{\circ} \mathrm{C}$ and then acidified $\left(\mathrm{HClO}_{4}-\mathrm{HF}-\mathrm{HNO} 3\right)$ at $110^{\circ} \mathrm{C}$ overnight before being evaporated and stored in a $5 \% \mathrm{HNO} 3$ solution. In addition to the abiotic pond matrices, bioaccumulation of heavy metals was tested in snails of the genus Lymnaea that were collected in the ponds. Snails were present in 14\% (18/99) and $27 \%$ (34/126) of the small ponds sampled during summer 2003 or spring 2004, respectively. A total of 48 ponds were investigated with 30-45 snails for each pond depending on population size of the snails. In the laboratory, snails were lyophilized and digested by acidified solution $\left(\mathrm{H}_{2} \mathrm{O}_{2}-\mathrm{HNO}_{3}\right)$, and stored in nitric acid $\left(5 \% \mathrm{HNO}_{3}\right)$. Then, concentrations of heavy metals were measured in the digested solutions using a highresolution quadruple-inductively coupled plasma-mass spectrophotometer (HR-ICP-MS). Multi-element standard solutions at different concentrations $(0,0.02,1,5$,
20,100 and $200 \mathrm{ppb}$ ) were used for calibration. Total variation coefficients of four replicate measurements varied between 1.66 and $5.45 \%$. Heavy metal levels in water were compared with the Belgian and international reference quality for surface waters: $1,50,50$, 200-300 $\mathrm{g} \mathrm{I}^{-1}$ and $770 \mathrm{ng} \mathrm{l}^{-1}$ for $\mathrm{Cd}, \mathrm{Pb}, \mathrm{Cu}, \mathrm{Zn}$ and $\mathrm{Hg}$, respectively (Delbeuck 2007; Reynders et al., 2008; USEPA, 2009; Rimondi et al., 2012), and those in the sediment were compared with the probable effect concentrations reported by MacDonald et al. (2000): 4.98, 149, 128 and $459 \mu \mathrm{g} \mathrm{l}^{-1}$ for $\mathrm{Cd}, \mathrm{Cu}, \mathrm{Pb}$ and $\mathrm{Zn}$, respectively.

\section{Statistical analyses}

Values are mean $\pm \mathrm{SD}$, and data expressed in percentages were log-transformed before statistical
Fig. 3 Seasonal changes (a, $n=$ number of ponds) and variation in isoproturon levels (b, $n=$ number of samples) in water sampled three times in ponds located in intensive and extensive agricultural areas or in natural reserves during 2007. Isoproturon contamination was more frequent in October and April, and values were higher $(P<0.05)$ in ponds located in agricultural areas than ponds in natural areas
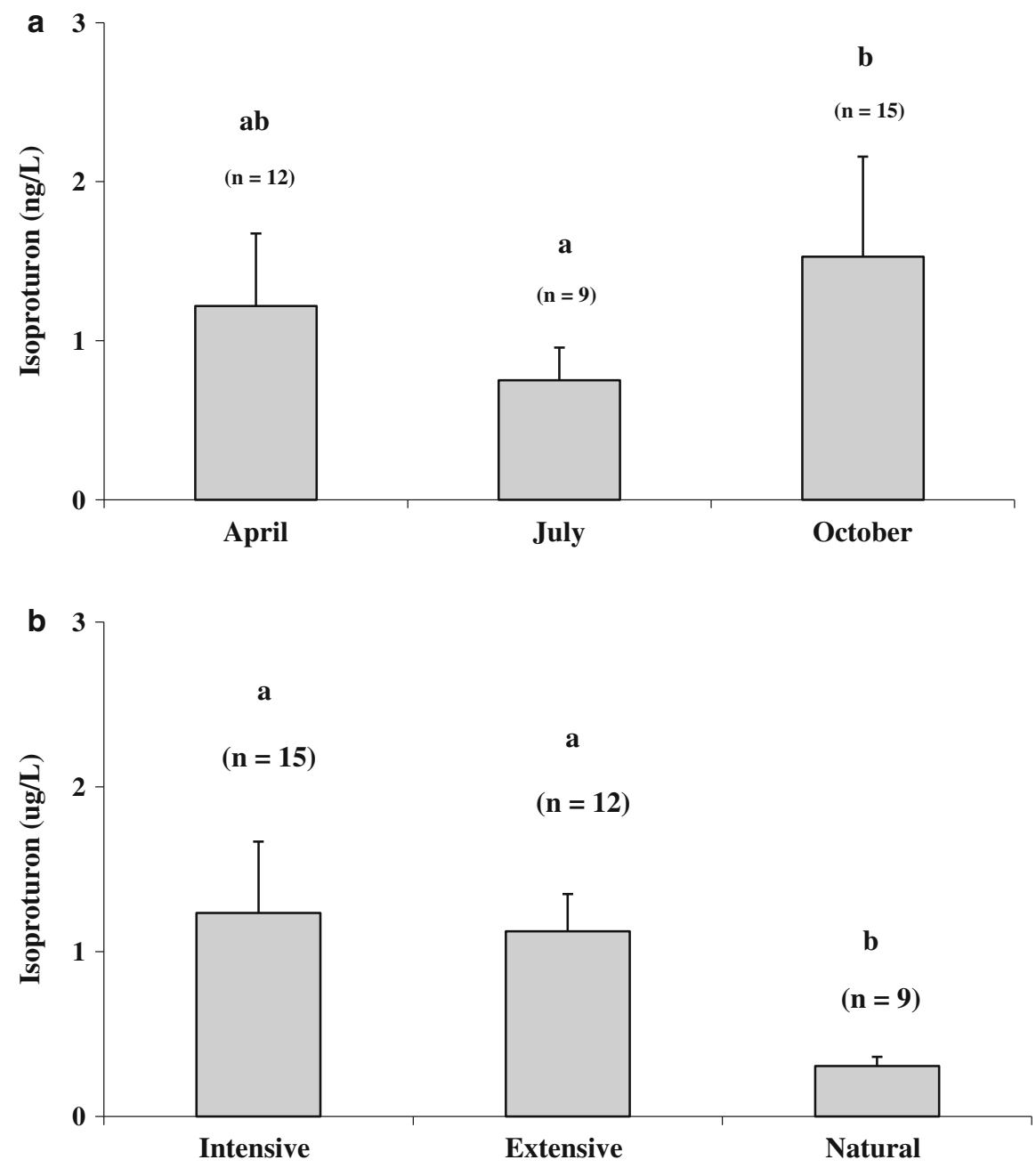
Fig. 4 Seasonal changes (a, $n=$ number of ponds) and variation in glyphosate and AMPA levels (b, $n=$ number of samples) in water sampled three times in ponds located in intensive and extensive agricultural areas or in natural reserves during year 2007.

Glyphosate and AMPA contamination was more frequent in October and April, and values were higher $(P<0.05)$ in intensive land-use ponds than in extensive land-use ponds or in ponds in natural areas
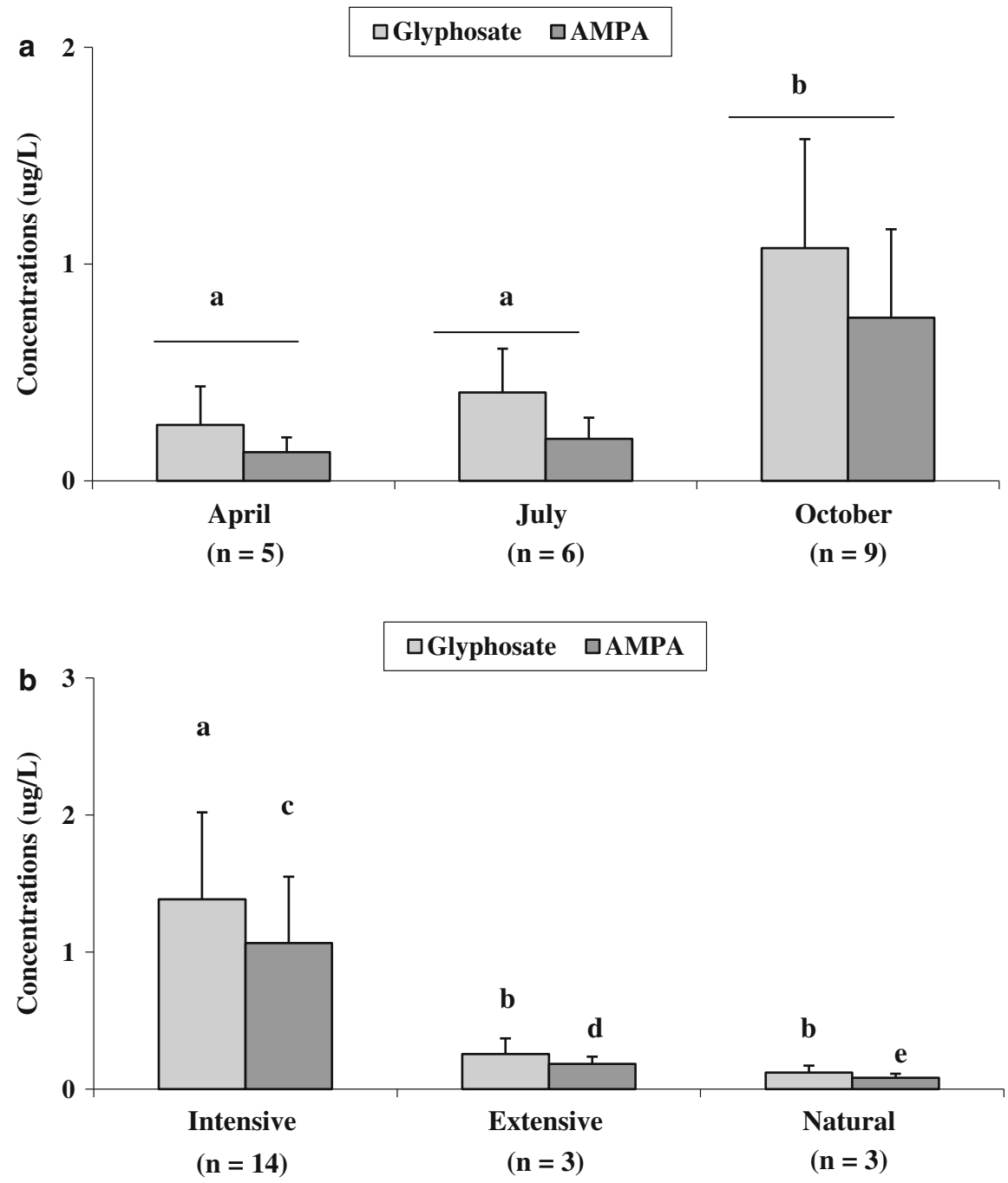

analyses. Homogeneity of data was tested by Bartlett's test, and then, ANOVA-II was used to test the main effect of the three types of ponds and season. Significance of differences between groups was estimated using the Scheffe's multiple range tests with a significance level at $P<0.05$. Calculations were performed using Statistica software (STATSOFT, Tulsa, OK, USA). Regression analysis was used to test the relationships between atrazine (the more frequent herbicide) levels in water and distance to crop fields as well as between sediment concentrations and snail concentrations for each metal.

\section{Results}

Pesticide levels in pond water

During the water sampling of 2004, atrazine was found in 42 ponds, at concentrations varying between 0.011 and $1.259 \mu \mathrm{g} \mathrm{l}^{-1}$. Atrazine was detected in $33 \%$ of the 126 investigated ponds, with their number increasing with land-use intensity: $6 \%$ of the ponds in nature reserves, $13 \%$ of the extensive land-use ponds and $23 \%$ of the intensive land-use ponds (Fig. 2a). In those ponds where atrazine was detected, concentrations were significantly $(P<0.05)$ higher in intensive land- 
use ponds than in extensive land-use ponds or ponds in natural areas (Fig. 2b). Overall, atrazine levels in the ponds were inversely related $(R=-73, P=9.44 \times$ $10^{-8}$ ) to the distance from the nearest crop field. Presence of other herbicides molecules was generally low but showed also a trend of more contamination in intensive ponds than in extensive ponds. Indeed, while no triazine metabolites were detected, simazine was detected in 5 intensive land-use and 3 extensive land-use ponds $(6.3 \%$ of the investigated ponds), at low concentrations $\left(0.010-0.156 \mu \mathrm{g} \mathrm{l^{-1 }}\right)$. Diuron was detected in $8.7 \%$ of the ponds, again predominantly located in agricultural areas (6 intensive land-use ponds, 3 extensive land-use ponds, and 2 ponds in nature reserves), at low concentrations varying between $0.010-0.161 \mu \mathrm{g}^{-1}$. No other targeted pesticides (isoproturon, endosulfan and lindane) were detected during the 2004 sampling campaign.
During the 2007 sampling campaign, no triazines or other pesticides were detected except for isoproturon and glyphosate. Concentrations of these two herbicides were relatively low but showed important seasonal variations. Isoproturon levels were significantly $(P<0.05)$ higher in October and April than in July (Fig. 3a). All intensive land-use ponds and all extensive land-use ponds were contaminated by isoproturon, and all but three extensive land-use ponds had isoproturon irrespective of sampling season. All five ponds in natural areas were also contaminated by isoproturon in October, but three samples of April and July did not reveal contamination. Similar to our observations for atrazine in 2004, isoproturon concentrations were higher $(P<0.05)$ in intensive land-use ponds (0.15-3.81 $\left.\mathrm{g} \mathrm{I}^{-1}\right)$ compared to extensive land-use ponds $\left(0.90-2.13 \mu \mathrm{g} \mathrm{l}^{-1}\right)$ or ponds in natural areas (0.01-0.61 $\mu \mathrm{g} \mathrm{l}^{-1}$ ) (Fig. 3b).
Fig. 5 Profiles of plasma vitellogenin levels (a) and brain aromatase activity (b) in sedentary Prussian carp juveniles sampled in ponds located in intensive and extensive agricultural areas in 2008 and 2009. $N=30$ juveniles. No modulation was observed in plasma VTG or brain aromatase activity in males, whatever the type of pond the fish were sampled from
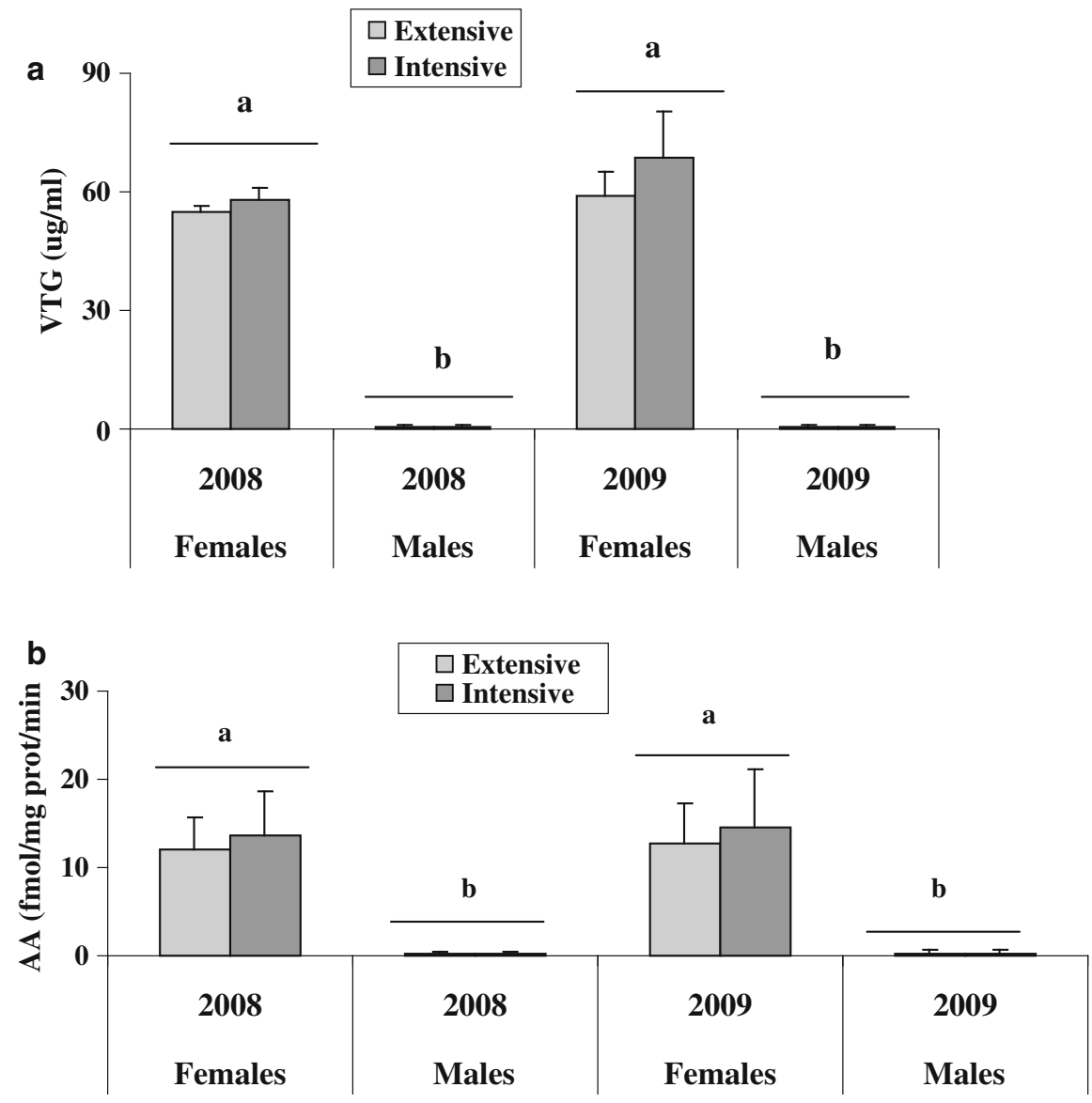

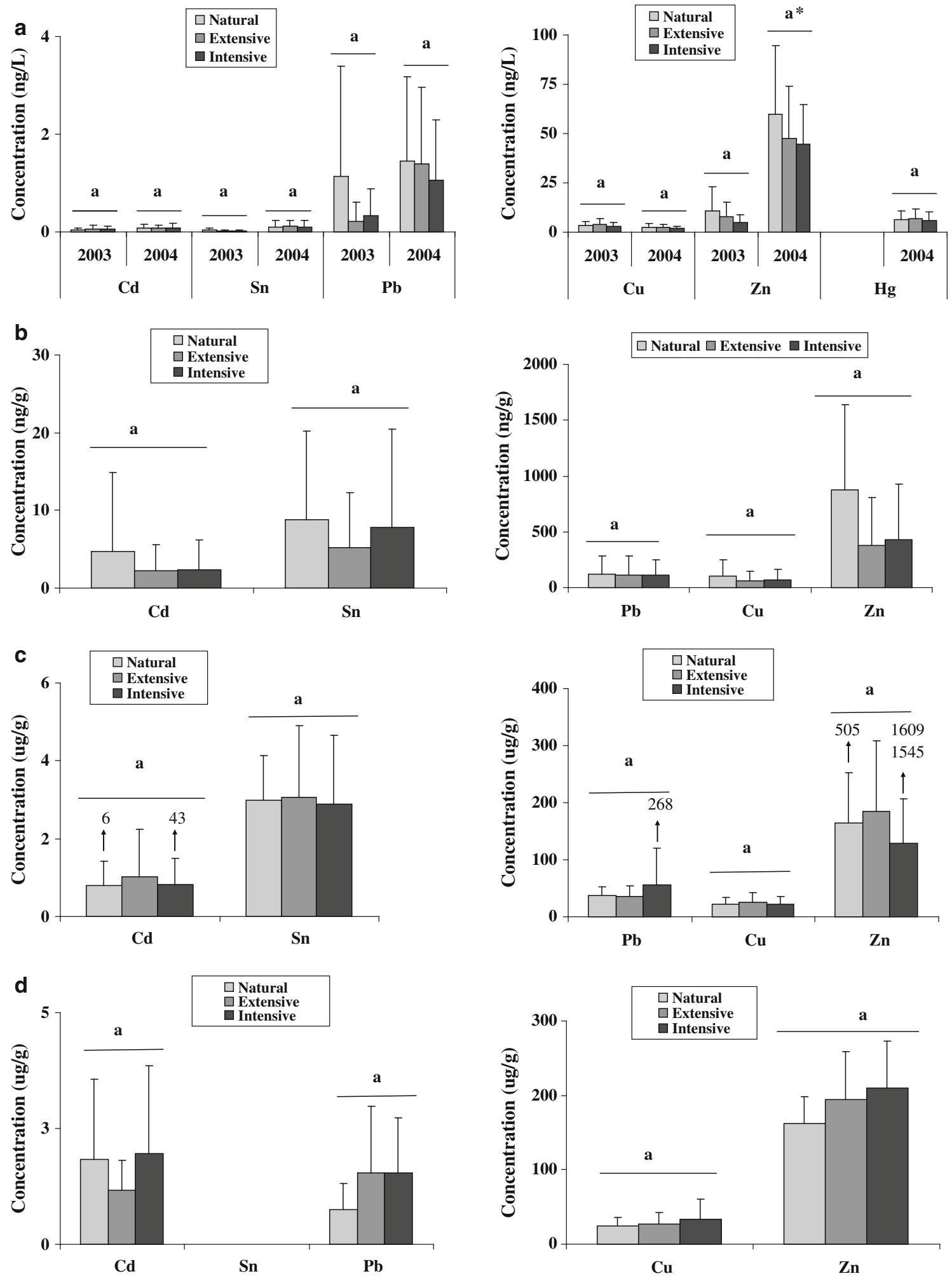
4 Fig. 6 Variation in heavy metal concentrations in water (a), suspended solids (b), sediment (c) or snail homogenates sampled in ponds in intensive and extensive agricultural areas or in ponds in natural reserves during summer 2003 or spring 2004. No significant effect of land-use intensity on heavy metal concentrations was observed whatever the pond matrix

Overall, glyphosate concentrations were low, with overall higher concentrations $(P<0.05)$ in October than in July and April (Fig. 4a). All five intensive landuse ponds were contaminated by glyphosate herbicides whatever the sampling season, while this was observed in only three extensive land-use ponds and ponds in natural areas. In addition, in those ponds where glyphosate herbicides were detected, concentrations were significantly higher $(P<0.05$, Fig. $4 b)$ in intensive land-use ponds $\left(0.541-2.075 \mu \mathrm{g} \mathrm{l}^{-1}\right)$ than in other pond types (extensive land use: $0.130-0.397 \mu \mathrm{g}^{-1}$, natural areas: $0.060-0.190$ ponds).

AMPA levels showed the same profiles as for glyphosate herbicides (Fig. 4a-b). Concentrations of insecticides (aldrine, chlorfenvinphos, $\alpha$-endosulfan, dicofol) and industrial compounds (octylphenol and 4-(para)-nonylphenol and $4 \mathrm{PAH}$ molecules) were below the detection limits in all ponds.

\section{Reproductive disruption features}

wAs expected, plasma VTG levels were markedly higher $(P<0.001)$ in female $\left(16-88 \mu \mathrm{g} \mathrm{ml}^{-1}\right)$ than in male $\left(0.00-1.47 \mu \mathrm{g} \mathrm{ml}^{-1}\right)$. VTG values were lower than the detection limits $\left(0.010 \mu \mathrm{g} \mathrm{ml}^{-1}\right)$ for $50 \%$ of the tested males (Fig. 5a). Levels of brain aromatase activity were markedly lower $(P<0.001)$ in males (0.00-1.78 $\mathrm{fmol} \mathrm{mg}^{-1}$ prot $\left.^{-1} \mathrm{~min}^{-1}\right)$ than in females (6.55-17.94 fmol mg ${ }^{-1} \operatorname{prot}^{-1} \mathrm{~min}^{-1}$ ), and values did not differ between fish from intensive and extensive land-use ponds (Fig. 5b). Only one intersex individual was observed in each type of ponds ( 2 out of 120 fish screened $=1.7 \%)$. In these intersexual fish, a high level of aromatase activity (19-23 fmol mg ${ }^{-1} \operatorname{prot}^{-1} \min ^{-1}$ ) and plasma VTG values (48-71 $\mu \mathrm{g} \mathrm{ml}^{-1}$ ) comparable to values observed in females was observed. Both for females (1.8-3.4\%) and males (0.65-1.25\%), GSI values varied strongly between individuals, and no significant differences were observed between males from intensive land-use $(0.85 \pm 0.1 \%)$ and extensive land-use $(0.94 \pm 0.3 \%)$ ponds. The two intersex fish displayed higher GSI values $(2.45 \%)$ than normal males and females.
Heavy metals

For all analysed heavy metals, no effect of land-use intensity was observed in any of the studied pond matrices (Fig. 6a-d). In the pond water, total concentrations $\left(\mathrm{ng}^{-1}\right.$ ) of Cd (range 0.00-0.44), Sn (range $0.00-0.14), \quad \mathrm{Pb}$ (range 0.08-2.66), $\mathrm{Zn}$ (range 0.85-5.82) and $\mathrm{Hg}$ (range 0.56-19.97) were near the detection limits (Fig. 6a). Concentrations of $\mathrm{Zn}$ were significantly $(P<0.05)$ higher in 2007 compared to 2004, but concentrations were generally low $\left(<0.1 \mu \mathrm{g} \mathrm{l}^{-1}\right)$ in most of the ponds. In suspended materials (Fig. 6b), $\mathrm{Zn}$ levels were the highest (0.1-1.7 $\left.\mu \mathrm{g} \mathrm{g}^{-1}\right)$ of all metals, and concentrations were very low for the other metals, varying between 0 and $20 \mathrm{ng} \mathrm{l}^{-1}$ for $\mathrm{Cd}$ and $\mathrm{Sn}$ and $0.1-0.9 \mu \mathrm{g} \mathrm{g}^{-1}$ for $\mathrm{Pb}$ and $\mathrm{Cu}$. As expected, contents of heavy metals in sediment (Fig. 6c) were significantly higher than in water $(P<0.0001)$ or suspended materials $(P<0.001)$. The lowest values in sediment were observed for Cd or Sn (0.05-1.72 or 1.4-4.56 $\mu \mathrm{g} \mathrm{g}^{-1}$ ) and the highest ones for $\mathrm{Zn}\left(61.98-505 \mu \mathrm{g} \mathrm{g}^{-1}\right)$. Levels for $\mathrm{Pb}$ and $\mathrm{Cu}$ varied between 9.17-93.80 and 3.73-84.40 $\mu \mathrm{g} \mathrm{g}^{-1}$, respectively. For all the investigated heavy metals in sediment, values were lower than the minimum effect concentrations, except in $8.8 \%$ of the agricultural or natural ponds. Accumulation of heavy metals in snail homogenates (Fig. 6d) reflected tightly the levels found in the sediments and not those in water or suspended materials. Indeed, sediment concentrations were significantly correlated to snail concentrations (Table 3 ) for all metals except for $\mathrm{Cu}$ and $\mathrm{Sn}$; specifically $\mathrm{Pb}(R=0.99, P=0.000)$ and $\mathrm{Zn}(R=0.65, P=0.001)$ sediment concentrations were well related to snail concentrations.

Table 3 Coefficients of correlations between values for heavy metal $(\mathrm{Cd}, \mathrm{Zn}, \mathrm{Cu}, \mathrm{Pb})$ concentrations in snails and in sediments sampled in ponds located in intensive and extensive agricultural areas or in natural reserves during spring 2004

\begin{tabular}{lll}
\hline & $R$ & $P$ \\
\hline $\mathrm{Cd}$ & 0.49 & 0.027 \\
$\mathrm{~Pb}$ & 0.99 & 0.000 \\
$\mathrm{Cu}$ & 0.38 & 0.071 \\
$\mathrm{Zn}$ & 0.65 & 0.001 \\
\hline
\end{tabular}

Sediment concentrations were closely related to snail values, except for only $\mathrm{Sn}$; $\mathrm{Hg}$ was not assayed in snails or sediment 


\section{Discussion}

Pesticide pollution

Regular follow-ups of pesticide pollution loads are often made for large lakes and rivers, but information is generally lacking for small water bodies such as ponds. Here, we tested whether ponds suffer from pesticide contamination and whether this is related to current land use and land-use intensity. In our survey of 126 ponds, atrazine was detected in $33 \%$ of the investigated ponds, but the overall concentrations were low. Given the ban on this herbicide by the European Union (2004/248/EG), the fact that we still detected it in $1 / 3$ of the ponds sampled in 2004 may indicate that atrazine molecule does not break down easily in pond water conditions. In other surface waters, the half-time for the dissipation of atrazine is reported ranging between 4 and 11 months depending to water physico-chemical conditions (Mouvet et al., 1997; Sørensen et al., 2003; Tissier et al., 2005). But apart from a possible long-term stability of atrazine in the pond water conditions, the current observation could also be an evidence of a continued use of atrazine since the sampling campaign was conducted not far from the ban regulation. The percentages of atrazine contamination increased markedly with the increase in land-use intensity, with both the number of contaminated ponds and the average concentrations of atrazine in the contaminated ponds being higher in intensive land-use compared to the other ponds and higher in the extensive land-use ponds than in the ponds in natural areas. In our 2007 survey, no triazine herbicides, insecticides or industrial compounds were detected. In this survey, however, we detected the presence of the herbicides isoproturon and glyphosate (and its derivative AMPA) in the majority (glyphosate) or even in all ponds. Such results indicate historical changes in the use of pesticides in relation to the EU regulation concerning atrazine, which led to the use of other pesticide molecules. For both the herbicides detected, there was an increase in concentration from ponds in natural areas over extensive to intensive land-use ponds. Overall, our analyses did not reveal very high concentrations but did show that herbicides are detected frequently, with a clear impact of land use on the probability of occurrence and observed concentrations. Declerck et al. (2006) showed that land-use intensity in the immediate neighbourhood (100-200 m) of the ponds strongly impact water quality variables such as turbidity and nutrient concentrations. Here, we show that cropland and agricultural activities in general in the neighbourhood of the ponds lead to increased concentrations of herbicides in the water. Irrespective of this clear impact of land use, a considerable fraction of ponds in nature reserves was also contaminated. Overall, our results do reveal lower concentrations of herbicides than measured in rivers and lakes (Delbeuck, 2005, 2008). Given the importance of distance to cropland and land-use intensity in the immediate neighbourhood of the ponds, our results suggest that the creation of a sizeable buffer zone $(\gg 50 \mathrm{~m})$ where no crops may be cultured around ponds might help to mitigate spray-drift input in ponds.

Due to the current widespread use of phenyl urea in agricultural production and as a total herbicide in urban areas, isoproturon is amongst the contaminants most frequently encountered in rivers, streams, lakes, marine waters and groundwater in Belgium and other European countries (Thurman et al., 2000; Gerecke et al., 2001; Sørensen et al., 2003; Delbeuck, 2005, 2008, 2010). It has also been reported that heavy rainfall subsequent to herbicide applications in spring may lead to contamination of aquatic environments by run-off (Polard et al., 2011). Indeed, it is well known that herbicide contamination negatively affects the welfare of aquatic animals by altering the food availability and habitat or some interactions between biotas such as dominance of predators. All herbicides detected in the present study have been reported to act directly on various physiological pathways of aquatic animals. High levels of atrazine are still of concern for groundwater in Belgium (Delbeuck, 2010) as in the US and other countries (Gillion et al., 2006 in Tillitt et al., 2010). Atrazine has been reported to act as endocrine disruptor, but the data are still controversial in fish (Kazeto et al., 2004; Spanò et al., 2004; Hinfray et al., 2006; Nadzialek et al., 2008; Tillitt et al., 2010). Studies on amphibians converge to the conclusion that atrazine used at environmental concentrations has marked endocrine disrupting effects that affect the central nervous and immune system of frogs and salamanders (Sparling et al., 2001; Forson \& Storfer, 2006; Kloas et al., 2009; Lasserre et al., 2009; Hayes et al., 2010a, b). Despite massive use of isoproturon for various purposes and its possible release in the environment, information is still scarce about the long- 
term effects of exposure to chronic low levels of this herbicide in animals. Greulich et al. (2002) reported that levels of $10 \mu \mathrm{g}^{-1}$ of isoproturon in water can affect the detoxification enzymatic system in tadpoles of various amphibian species. Our study confirms earlier observations that isoproturon and glyphosate herbicides are nowadays amongst the most frequently encountered pesticides (Delbeuck, 2005, 2008). High concentrations of glyphosate herbicides have been found in pond environments in both Europe and the USA, with deleterious effects on aquatic animals, including the disturbance in the metamorphosis process, tail damages, endocrine disruption and gonad abnormalities (Howe et al., 2004; Brausch \& Smith, 2007; Dinehart et al., 2009, 2010). Since glyphosate herbicides are now massively used everywhere, more studies are needed to clarify the long-term effects of low concentrations of these pesticides on aquatic organisms.

Simazine and diuron were detected at very low concentrations and in only a few ponds (survey 1). None of the tested insecticides (aldrine, chlorfenvinphos, $\alpha$-endosulfan, dicofol) or industrial compounds (octylphenol, nonylphenol and 4 PAHs) were detected in survey 2 . This may be due to the fact that the ponds are relatively isolated in the landscape, and thus less likely to become contaminated except for application in their immediate neighbourhood. Despite the fact that these insecticides have been banned in European countries, they are still found in rivers and streams (Delbeuck, 2007) at low concentrations due to their persistence in sediments and a regular solubilization process through the water column. Many studies on rivers and streams do show contamination by phenolic compounds (Micic \& Hofmann, 2009) and PAHs (Delbeuck, 2007, 2008, 2010; Wu et al., 2011; An et al., 2012).

\section{Endocrine disruption in resident fish}

To test whether the presence of some pesticides or other pollutants was missed in the pond water and to better understand their effects on aquatic pond animals, reproductive disruption biomarkers were examined in resident Prussian carp. This subspecies of goldfish is amongst the more abundant fish species found in farmland ponds in Belgium and has already been used as a sensitive sentinel for detecting exposure to various endocrine disruptors such as $17-\beta$ estradiol and 4-nonylphenol (Soverchia et al., 2005; Popesku et al., 2008). In the present study, intersex incidence $(1.7 \%)$ was comparable to that observed in other regions in reference rivers for some cyprinid fish species (0-41\%) such as chub Leuciscus cephalus, roach Rutilus rutilus and gudgeon Gobio gobio (Van Aerle et al., 2001; Jobling et al., 2002; Randak et al., 2009; Hinfray et al., 2010). Moreover, VTG concentrations in males $\left(0.00-1.47 \mu \mathrm{g} \mathrm{ml}^{-1}\right)$ did not indicate a disturbance in endocrine production and were in the same order of magnitude as those measured in some male cyprinid fish such as roach (0.047-1.502 $\mu \mathrm{g} \mathrm{ml}^{-1}$ ) from reference stream sites (Tyler et al., 2005). VTG values were lower than values reported for male cyprinid chub from contaminated stream sites, which can reach $49 \mu \mathrm{g} \mathrm{ml}^{-1}$ (Hinfray et al., 2010). In relation to VTG levels, low brain aromatase activity confirmed the lack in upregulation of endocrine production. Values for aromatase activity were indeed comparable to those reported for some cyprinid fish from river systems (Noaksson et al., 2001; Hecker et al., 2007; Hinfray et al., 2010). Since the two latter investigated endocrine features have been reported as reliable biomarkers of pesticide exposure for various aquatic organisms (Folmar et al., 2001; Hayes et al., 2006; Wingfield \& Mukai, 2009; Desforges et al., 2010; Nadzialek et al., 2011), the lack of their up-regulation in fish inhabiting the ponds reflects the absence (or presence at very low concentrations) of oestrogenic pollutants in the pond water. The results of the present study indicate that fish inhabiting the farmland ponds studied were not affected by endocrine disruptors.

Heavy metals

For the tested heavy metals (Cd, $\mathrm{Sn}, \mathrm{Pb}, \mathrm{Cu}, \mathrm{Zn}, \mathrm{Hg}$ ), levels in water and suspended materials were about 100 times lower than those usually measured in the same matrices from rivers and streams in Belgium (Bervoest \& Blust, 2003; Delbeuck, 2007). Apart from $\mathrm{Sn}$, the tested heavy metals are considered problematic in surface waters in Belgium and in many other countries, but in the present study, none were found at concentrations higher than the European or US criteria of good quality surface water (Delbeuck, 2007; Reynders et al., 2008; USEPA, 2009; Rimondi et al., 2012). Zn concentrations increased markedly in 2004 compared to 2003 , but values were still markedly 
lower $\left(<0.1 \mu \mathrm{g} \mathrm{l}^{-1}\right)$ than those reported for some lakes in Wallonia (0.93 $\mu \mathrm{g}^{-1}$, Delbeuck, 2007) and contaminated sites in rivers in Flanders (109-2,369 $\mathrm{g} \mathrm{l}^{-1}$, Reynders et al., 2008). This increase in $\mathrm{Zn}$ levels may be related to higher rainfall during the sampling campaign in 2004 compared to that in 2003, resulting in higher run-off of heavy metals in the pond water or in an increased in situ geochemical transfer of some metals from the sediment layer to the water column. As expected, concentrations of heavy metals were higher in sediment than in water and in suspended solids, but values were still lower than those found in other, larger water bodies (Delbeuck, 2007; Reynders et al., 2008). In some ponds, levels for $\mathrm{Cu}$ and $\mathrm{Pb}$ were higher than those typically reported for rivers in Flanders (Bervoest \& Blust, 2003), but for all the tested heavy metals, values were lower than minimal effect concentrations as determined for aquatic organisms (MacDonald et al., 2000).

No significant effect of land-use intensity on heavy metal concentrations was observed. It has been shown that the concentrations of some heavy metal, such as $\mathrm{Cu}$, $\mathrm{Cd}$ and $\mathrm{Zn}$, may be increased in agricultural areas due to sewage sludge and fertilizer use (Nicholson et al., 2003; Mass et al., 2010), but overall especially industrial activities are historically associated with heavy metal pollution (Loska et al., 2004; Reynders et al., 2008). Isolated ponds such as those tested in the current study may be relatively spared from pollution by heavy metals and industrial such as PAHs. Exceptions would be ponds located in the immediate vicinity of sources or ponds that are regularly flooded by large water.

We established a significant relation between heavy metal concentrations in sediment and accumulation in the snails, indicating that snails are reliable sentinel species for heavy metal pollution in pond environment. Concentrations of heavy metals in snails were for some metals, such as $\mathrm{Cd}$ and $\mathrm{Cu}$, comparable to those reported in other snail species (such in Melanopsis praemorsa and Theodoxus jordani) or higher than values reported for other species (such in Perna perna, Dosinia sp. or Donax rugosus), even though the water bodies in these other studies were characterized by higher concentrations of heavy metals (Swailek et al., 1994; Sidoumou et al., 2006). In contrast, while Sn was present in all pond matrices, only trace levels were observed in the snails, indicating a low uptake or high elimination rate (Grosell \& Brix, 2009;
Moloukhia \& Sleem, 2011) of this metal by the snails. It has been reported that snail species differ strongly in heavy metal accumulation and are more sensitive to metal pollution than other aquatic animals such as fish (Voets et al., 2006; Ng et al., 2011; Moloukhia \& Sleem, 2011). In general, metal exposure is followed by a rapid activation of detoxification pathway defence, such as the increase in specific granules in the digestive gland cells for metal sequestration and the induction of metallothionein production by lysosomal granules in the endoplasmic reticulum for metal binding and excretion (Desouky, 2006, Voet et al., 2006; $\mathrm{Ng}$ et al., 2011). Despite the efficiency of the detoxification mechanism, long-term exposure of aquatic animals to metal pollution is detrimental to their fitness because the energy requested for detoxification defence is re-allocated from normal physiological functions such as growth and reproduction (De Coen \& Janssen, 2003; $\mathrm{Ng}$ et al., 2011). Some toxicological studies have also suggested a link between metal exposure and reproductive impairment in fish populations (Boyle et al., 2008); high levels of some heavy metals such as Cd could delay oocyte maturation and ovulation by disturbing the vitellogenesis process rather than the pituitary pathway control in Prussian carp (Szczerbik et al., 2006). A recent study demonstrated that $\mathrm{Cu}$ or $\mathrm{Cd}$ itself has no direct effect on VTG expression but may increase the oestrogenic-VTG induction level comparing to a single oestrogenic exposure in goldfish (Chang et al., 2011), but no abnormal increase in the levels of plasma vitellogenin was observed both in males and females in the current study. In the current study, concentrations $\mathrm{Cu}$ or $\mathrm{Cd}$ were low in all the tested pond matrices, and no alteration in brain aromatase activity or circulating vitellogenin level was observed in Prussian carp inhabiting representative pond environment of the Belgian intensive or extensive land-use ponds.

\section{Conclusions}

The overall results of our survey study demonstrated that small Belgian ponds were mainly contaminated by some herbicides and sporadic high discharges of heavy metals in sediment and snails, and that pond sedentary fish were not affected by endocrine disruptors. Our results also demonstrated a marked effect of agricultural land-use intensity on herbicide pollution, 
which would be mitigated by an adjustment of the land use in the immediate neighbourhood of the pond or the use of sufficiently large buffer zones.

Acknowledgements We thank A. Evrard for help with the fieldwork. This study was financially supported by the Belgian federal Science Policy (Belspo) in the framework of the PODO II-program, project MANSCAPE (EV/01/29E), and the SDDprogram, project PONDSCAPE (SD/BD/02).

\section{References}

An, L., B. Zheng, L. Wang, Y. Zhang, H. Chen, X. Zhao, L. Zhang \& K. Lei, 2012. Biomarker responses and genotoxicity in the mud snail (Bullacta exarata) as indicators of coastal contamination. Marine Pollution Bulletin 64: 303-309.

Barni, S., E. Boncompagni, A. Grosso, V. Bertone, I. Freitas, M. Fasola \& C. Fenoglio, 2007. Evaluation of Rana snk esculata blood cell response to chemical stressors in the environment during the larval and adult phases. Aquatic Toxicology 81: 45-54.

Bervoest, L. \& R. Blust, 2003. Metal concentrations in water, sediment and gudgeon (Gobio gobio) from a pollution gradient: relationship with fish condition factor. Environmental Pollution 126: 9-19.

Bonnet, J. L., F. Bonnemoy, M. Dusser \& J. Bohatier, 2007. Assessment of the Potential Toxicity of Herbicides and Their Degradation Products to Nontarget Cells Using Two Microorganisms, the Bacteria Vibrio fischeri and the Ciliate Tetrahymena pyriformis. Environmental Toxicology 22: 78-91.

Boyle, D., K. V. Brix, H. Amlund, A. K. Lundebye, C. Hogstrand, \& N. R. Bury, 2008. Natural arsenic contaminated diets perturb reproduction in fish. Environmental Science Technology 42: 5354-5360.

Brasseur, C., F. Brose, A. Pirlot, C. Douny, G. Eppe, G. Maghuin-Rogister \& M. L. Scippo, 2007. Validation of the analytical procedure for the determination of polyaromatic hydrocarbons in smoke flavourings using high performance liquid chromatography coupled to an ultraviolet, diode array or fluorescence detector. Accred Qual Assur 12: 535-542.

Brausch, J. M. \& P. N. Smith, 2007. Toxicity of three polyethoxylated tallowamine surfactant formulations to laboratory and field collected fairy shrimp, Thamnocephalus platyurus. Arch. Environ Contam Toxicol 52: 217-221.

Chang, Z., M. Lu, K. Woo, B.-S. Oh, M.-J. Bae \& J.-S. Park, 2011. Influence of divalent metal ions on E2-induced ER pathway in goldfish (Carassius auratus) hepatocytes. Ecotoxicology and Environmental Safety 74: 2233-2239.

Danion, M., S. Le Floch, R. Kanan, F. Lamou \& C. Quentel, 2011. Effects of in vivo hydrocarbons pollution on sanitary status and immune system in sea bass (Dicentrarchus labrax L.). Aquatic Toxicology 105: 300-311.

Davies, B. R., J. Biggs, P. J. Williams, J. T. Lee \& S. A. Thompson, 2008. Comparison of the catchment sizes of rivers, streams, ponds, ditches and lakes: implications for protecting aquatic biodiversity in an agricultural landscape. Hydrobiologia 597: 7-17.

De Coen, W. M. \& C. R. Janssen, 2003. The missing biomarker link: relationships between effects on the cellular energy allocation biomarker of toxicant stressed Daphnia magna and corresponding population characteristics. Environ Toxicology and Chemistry 22: 1632-1641.

Declerck, S., T. De Bie, D. Ercken, H. Hampel, S. Schrijvers, J. Van Wichelen, V. Gillard, S. N. M. Mandiki, B. Losson, D. Bauwens, S. Keijers, W. Vyverman, B. Goddeeris, L. De Meester, L. Brendonck \& K. Martens, 2006. Ecological characteristics of small farmland ponds: associations with land-use practices at multiple spatial scales. Biological Conservation 131: 523-532.

Delbeuck, C. 2005, 2007, 2008, 2010. Tableau de bord de l'environnement wallon. In Cellule Etat de l'Environnement wallon, SPW-DGARNE (eds), see also, http:// environnement.wallonie.be.

Desforges, J. P. W., B. D. L. Peachey, P. M. Sanderson, P. A. White, M. Jules \& J. L. Blais, 2010. Plasma vitellogenin in male teleost fish from 43 rivers worldwide is correlated with upstream human population size. Environmental Pollution 158: 3279-3284.

Desouky, M. M. A., 2006. Tissue distribution and subcellular localisation of trace metals in the pond snails Lymnaea stagnalis with special reference to the role of lysosomal granules in metal sequestration. Aquatic Toxicology 77: $143-152$.

Dinehart, S. K., L. M. Smith, S. T. McMurry, T. A. Anderson, P. N. Smith \& D. A. Haukos, 2009. Toxicity of a glufosinate and several glyphosate-based herbicides to juvenile amphibians from the Southern high plains, USA. Science of Total Environment 407: 1065-1071.

Dinehart, S. K., L. M. Smith, S. T. McMurry, P. N. Smith, T. A. Anderson \& D. A. Haukos, 2010. Acute and chronic toxicity of Roundup Weathermax and Ignite 280 SL to larval Spea multiplicata and S. bombifrons from the Southern High Plains, USA. Environmental Pollution 158: 2610-2617.

Fatima, M., S. N. M. Mandiki, J. Douxfils, J. Silvestre, P. Coppe \& P. Kestemont, 2007. Combined effects of herbicides on biomarkers reflecting immune-endocrine interactions in goldfish. Immune and antioxidant effects. Aquatic Toxicology 81: 159-167.

Folmar, L. C., N. D. Denslow, K. Kroll, E. F. Orlando, J. Enblom, J. Marcino, C. Metcalfe \& L. Guillette, 2001. Altered serum sex steroids and vitellogenin induction in walleye (Stizostedion vitreum) collected near a metropolitan sewage treatment plant. Archives of Environmental contamination and Toxicology 40: 392-398.

Forson, D. D. \& A. Storfer, 2006. Atrazine increases ranavirus susceptibility in the tiger salamander, Ambystoma tigrinum. Ecological Applications 16: 2325-2332.

Gerecke, A. C., C. Tixier, T. Bartels, R. P. Scharzenbach \& S. R. Muller, 2001. Determination of phenylurea herbicides in natural waters at concentrations below $1 \mathrm{ng} \mathrm{L}^{-1}$ using solid-phase extraction, derivatization, and solid-phase microextraction gas chromatography-mass spectrometry. Journal of Chromatography A 930: 9-19.

Gillardin, V., F. Silvestre, M. Dieu, E. Delaive, M. Raes, J. P. Thomé \& P. Kestemont, 2009. Protein expression 
profiling in the African clawed frog Xenopus laevis tadpoles exposed to the polychlorinated biphenyl mixture aroclor 1254. Molecular Cell Proteomics 2009(8): 596-611.

Gonzales, A. \& F. Piferrer, 2003. Characterization of aromatase activity in the sea bass (Dicentrarchus labrax L.) brain. Distribution and relation to age, sex, and the annual reproductive cycle. General and Comparative Endocrinology 132: 223-230.

Greulich, K., E. Hoque \& S. Pflugmacher, 2002. Uptake, metabolism and effects on detoxication enzymes of isoproturon in spawn and tadpoles of amphibians. Ecotoxicology and Environmental Safety 52: 256-266.

Grosell, M. \& K. V. Brix, 2009. High net calcium uptake explains the hypersensitivity of the pulmonate snail, Lymnaea stagnalis, to chronic lead exposure. Aquatic Toxicology 91: 302-311.

Guo, J., F. Wu, X. Luo, L. Zhang, H. Liao, R. Zhang, W. Li, X. Zhao, S. Chen \& B. Mai, 2011. Anthropogenic input of polycyclic aromatic hydrocarbons into five lakes in Western China. Environmental Pollution 158: 2175-2180.

Hayes, T. B., P. Case, S. Chui, D. Chung, C. Haeffele, K. Haston, M. Lee, V. P. Mai, Y. Marjuoa, J. Parker \& M. Tsui, 2006. Pesticide mixtures, endocrine disruption, and amphibians: are we underestimating the impacts? Environmental Health Perspectives 114: 40-50.

Hayes, T. B., P. Falso, S. Gallipeau \& M. Stice, 2010a. The cause of global amphibian declines: a developmental endocrinologist's perspective. The Journal of Experimental Biology 213: 921-933.

Hayes, T. B., V. Khoury, A. Narayana, M. Nazira, A. Parka, T. Browna, L. Adamea, E. Chana, D. Buchholz, T. Stuevea \& S. Gallipeaua, 2010b. Atrazine induces complete feminization and chemical castration in male African clawed frogs (Xenopus laevis). Proceedings of the National Academy of Sciences 107: 4612-4617.

Hecker, M., T. J. Sanderson \& L. Karbe, 2007. Suppression of aromatase activity in populations of bream (Abramis bra$m a$ ). Chemosphere 66: 542-552.

Hinfray, N., J. M. Porcher \& F. Brion, 2006. Inhibition of rainbow trout (Oncorhynchus mykiss) P450 aromatase activities in brain and ovarian microsomes by various environmental substances. Comp Biochem Physiol C Toxicol Pharmacology 144: 252-262.

Hinfray, N., O. Palluel, B. Piccini, W. Sanchez, S. Aït Aïssa, P. Noury, E. Gomez, P. Geraudie, C. Minier, F. Brion \& J. M. Porcher, 2010. Endocrine disruption in populations of chub (Leuciscus cephalus) in contaminated French streams. Science of the Total Environment 408: 2146-2154.

Howe, C. M., M. Berril, B. D. Pauli, C. C. Helbing, K. Werry \& N. Veldhoen, 2004. Toxicity of glyphosate-based pesticides to North American frog species. Environmental Toxicology Chemistry 23: 1928-1938.

Ibáñez, M., O. J. Pozo, J. V. Sancho, F. J. López \& F. Hernández, 2006. Re-evaluation of glyphosate determination in water by liquid chromatography coupled to electrospray tandem mass spectrometry. Journal of Chromatography 1134: 51-55.

Imperato, M., P. Adamo, D. Naimo, M. Arienzo, D. Stanzione \& P. Violante, 2003. Spatial distribution of heavy metals in urban soils of Naples (Italy). Environmental Pollution 124: 247-256.
Jobling, S. \& C. R. Tyler, 2006. Introduction: the ecological relevance of chemically induced endocrine disruption in wildlife. Environ Health Perspectives 114: 7-8.

Jobling, S., N. Beresford, M. Nolan, T. Rodgers-Gray, G. C. Brighty \& J. P. Sumpter, 2002. Altered sexual maturation and gamete production in wild roach (Rutilus rutilus) living in rivers that receive treated sewage effluents. Biology Reproduction 66: 272-281.

Kazeto, Y., A. R. Place \& J. Trant, 2004. Effects of endocrine disrupting chemicals on the expression of CYP19 genes in zebrafish (Danio rerio) juveniles. Aquatic Toxicology 69: 25-34.

Kloas, W., I. Lutz, T. Springer, H. Krueger, J. Wolf, L. Holden $\&$ A. Hosten, 2009. Does atrazine influence larval development and sexual differentiation in Xenopus laevis? Toxicology Science 107: 376-384.

Koeber, R., C. Fiescher, F. Lanza, K. S. Boos, B. Sellergren \& D. Barcelo, 2001. Evaluation of a multidimensional solidphase extraction platform for highly selective on-line clean-up and high-throughput LC-MS analysis of triazines in river water samples using molecularly in printing polymers. Analytical Chemistry 73: 2437-2444.

Lampi, M. A., J. Gurska, K. I. McDonald, F. Xie, X. D. Huang, D. G. Dixon \& B. M. Greenberg, 2006. Photoinduced toxicity of polycyclic aromatic hydrocarbons to Daphnia magna: ultraviolet-mediated effects and toxicity of polycyclic aromatic hydrocarbon photoproducts. Environmental Toxicology Chemistry 25: 1057-1087.

Lasserre, J. P., F. Fack, D. Revets, S. Planchon, J. Renaut, L. Hoffmann, C. Arno, A. C. Gutleb, C. P. Muller \& T. Bohn, 2009. Effects of the endocrine disruptors atrazine and PCB 153 on the protein expression of MCF-7 human cells. Journal of Proteome Research 8: 5485-5496.

Loska, K., D. Wiechula \& I. Korus, 2004. Metal contamination of farming soils affected by industry. Environment International 30: 159-165.

Maas, S., R. Scheifler, M. Benslama, N. Crini, E. Lucot, Z. Brahmia, S. Benyacoub \& P. Giaudoux, 2010. Spatial distribution of heavy metal concentrations in urban, suburban and agricultural soils in a Mediterranean city of Algeria. Environmental Pollution 156: 2294-2301.

MacDonald, D. D., V. G. Ingersoll \& T. A. Berger, 2000. Development and evaluation of consensus-based sediment quality guidelines for freshwater ecosystems. Archive Environmental Contamination Toxicology 39: 20-31.

Mandiki, S. N. M., I. Babiak, J. M. Bopopi, F. Leprieur \& P. Kestemont, 2005. Effects of sex steroids and their inhibitors on endocrine parameters and gender growth differences in Eurasian perch (Perca fluviatilis) juveniles. Steroids 70: 85-94.

Micic, V. \& T. Hofmann, 2009. Occurrence and behaviour of selected hydrophobic alkylphenolic compounds in the Danube River. Environmental Pollution 157: 2759-2768.

Milinkovitch, T., A. Ndiaye, W. Sanchez \& S. Le Floch, 2011. Thomas-Guyon H. Liver antioxidant and plasma immune responses in juvenile golden grey mullet (Liza aurata) exposed to dispersed crude oil. Aquat ic Toxicology 101: $155-164$.

Moloukhia, H. \& S. Sleem, 2011. Bioaccumulation, fate and toxicity of two heavy metals common in industrial wastes in two aquatics molluscs. Journal of American Science 7: 459-464. 
Mouvet, C., R. Jeannot, H. Riolland \& C. Maciag, 1997. Stability of isoproturon, bentazone, terbuthylazine and alachlor in natural groundwater, surface water and soil samples stored under laboratory conditions. Chemosphere 35: 1097-1997.

Nadzialek, S., L. L. Spano, S. N. M. Mandiki \& P. Kestemont, 2008. High doses of atrazine do not disrupt activity and expression of aromatase in female gonads of juvenile goldfish (Carassius auratus L.). Ecotoxicology 17: 464-470.

Nadzialek, S., C. Vanparys, E. Van der Heiden, C. Michaux, F. Brose, M. L. Scippo, W. De Coen \& P. Kestemont, 2010. Understanding the gap between the estrogenicity of an effluent and its real impact into the wild. Science of the Total Environment 408: 812-821.

Nadzialek, S., S. Depiereux, S. N. M. Mandiki \& P. Kestemont, 2011. In vivo biomarkers of estrogenicity: limitation and interpretation in wild environment. Archive Environmental Contamination 60: 471-478.

Ng, T. Y. T., N. M. Pais \& C. M. Wood, 2011. Mechanisms of waterborne $\mathrm{Cu}$ toxicity to pond snail Lymnaea stagnalis: physiology and $\mathrm{Cu}$ bioavailability. Ecotoxicology and Environmental Safety 74: 1471-1479.

Nicholson, F. A., S. R. Smith, B. J. Alloway, C. Carlton-Smith \& B. J. Chambers, 2003. An inventory of heavy metal input to agricultural soils in England and Wales. Science of the Total Environment 311: 205-219.

Nicolet, P., J. Biggs, G. Fox, M. J. Hodson, C. Reynolds, M. Whitfield \& P. Williams, 2004. The wetland plant and macroinvertebrate assemblages of temporary ponds in England and Wales. Biology Conservation 120: 261278.

Noaksson, E., U. Tjarnlund, A. T. C. Bosveld \& L. Balk, 2001. Evidence for endocrine disruption in perch (Perca fluviatilis) and roach (Rutilus rutilus) in a remote Swedish lake in the vicinity of a public refuse dump. Toxicology and Applied Pharmacology 174: 160-176.

Polard, T., S. Jeana, L. Gauthier, C. Laplanche, G. Merlina, J. M. Sánchez-Pérez \& E. Pinelli, 2011. Mutagenic impact on fish of runoff events in agricultural areas in south-west France. Aquatic Toxicology 101: 126-134.

Popesku, J. T., C. J. Mrtyniuk, J. Mennigen, H. Xiong, D. Zhang, X. Xia, A. R. Cossins \& V. L. Trudeau, 2008. The goldfish (Carassius auratus) as a model for neuroendocrine signaling. Molecular and Cellular Endocrinology 293: 43-56.

Randak, T., V. Zlabek, J. Pulkrabova, J. Kolarova, H. Kroupova, Z. Siroka, J. Vilisek, Z. Svobodova \& Z. Hasjlova, 2009. Effects of pollution on chub in the River Elbe, Czech Republic. Ecotoxicology and Environmental Safety 72: 737-746.

Reynaud, S. \& P. Deschaux, 2006. The effects of polycyclic aromatic hydrocarbons on the immune system of fish: a review. Aquatic Toxicology 77: 229-238.

Reynders, H., L. Bervoests, M. Gelders, W. M. De Coen \& R. Blust, 2008. Accumulation and effects of metals in caged carp and resident roach along a metal pollution gradient. Science of the Total Environment 391: 82-95.

Rhind, S. M., C. E. Kyle, C. Mackie, K. Yates \& E. I. Duff, 2011. Geographic variation in tissue accumulation of endocrine disrupting compounds (EDCs) in grazing sheep. Environmental Pollution 159: 416-422.
Rimondi, V., J. E. Gray, P. Costagliola, O. Vaselli \& P. Lattanzi, 2012. Concentration, distribution, and translocation of mercury and methylmercury in mine-waste, sediment, soil, water, and fish collected near the Abbadia San Salvatore mercury mine, Monte Amiata district, Italy. Science of the Total Environment 414: 318-327.

Rohr, J. R., A. M. Schotthoefer, T. R. Raffel, H. J. Carrick, N. Halstead, J. T. Hoverman, C. M. Johnson, L. B. Johnson, C. Lieske, D. Marvin, M. D. Piwoni, P. K. Schoff \& V. R. Beasley, 2008. Agrochemicals increase trematode infections in a declining amphibian species. Nature 455: 1235-1239.

Scheffer, M., G. J. van Geest, K. Zimmer, E. Jeppesen, M. Sondergaard, M. G. Butler, M. A. Hanson, S. Declerck \& L. De Meester, 2006. Small habitat size and isolation can promote species richness: second-order effects on biodiversity in shallow lakes and ponds. Oikos 112: 227-231.

Sidoumou, Z., M. Gnassia-Barelli, Y. Siau, V. Morton \& H. Romeo, 2006. Heavy metal concentrations in molluscs from the Senegal coast. Environmental International 32: 384-387.

Sørensen, S. R., G. D. Bending, C. S. Jacobsen, A. Walker \& J. Aamand, 2003. Microbial degradation of isoproturon and related phenylurea herbicides in and below agricultural fields. FEMS Microbiology 45: 1-11.

Soverchia, L., B. Ruggeri, F. Palermo, G. Mosconi, G. Cardinaletti, G. Scortichini \& A. M. Polzonetti-Magni, 2005. Modulation of vitellogenin synthesis through estrogen receptor beta-1 in goldfish (Carassius auratus) juveniles exposed to 17-ß estradiol and nonylphenol. Toxicology and Applied Pharmacology 209: 236-243.

Spanò, L., C. R. Tyler, R. Van Aerle, P. Devos, S. N. M. Mandiki, F. Silvestre, J. P. Thome \& P. Kestemont, 2004. Effects of atrazine on sex steroid dynamics, plasma vitellogenin concentration and gonad development in adult goldfish (Carassius auratus). Aquatic Toxicology 66: 369-379.

Sparling, D. W., G. M. Fellers \& L. L. McConnell, 2001. Pesticides and amphibian population declines in California, USA. Environmental Toxicology and Chemistry 20: 1591-1595.

Sun, K., B. Gao, Z. Zhang, G. Zhang, Y. Zhao \& B. Xing, 2010. Sorption of atrazine and phenanthrene by organic solids fractions in soil and sediment. Environmental Pollution 158: 3520-3526.

Swailek, K. M., M. N. Mesmar \& N. S. Ismail, 1994. Heavy metal concentrations in common freshwater snails of Azraq Oasis, Jordan. Hydrobilogia 286: 167-173.

Szczerbik, T., T. Mikolajczyk, M. Sokolowaska-Mikolajczyk, M. Socha, J. Chyb \& P. Epler, 2006. Influence of long-term exposure to dietary cadmium on growth, maturation and reproduction of goldfish (subspecies: Prussian carp Carassius auratus gibelio B.). Aquatic Toxicology 77: 126-135.

Thurman, E. M., K. C. Bastian \& T. Mollhagen, 2000. Occurrence of cotton herbicides and insecticides in Playa Lakes of the High Plains of West Texas. Science of the Total Environment 248: 189-200.

Tillitt, D., D. Papoulias, J. J. Whyte \& A. C. Richter, 2010. Atrazine reduces reproduction in fathead minnow (Pimephales promelas). Aquatic Toxicology 99: 149-159. 
Tissier, C., C. Morvan, G. Bocquené, H. Grossel, A. James \& M. Marchand, 2005. Les substances prioritaires de la Directive Cadre sur l'Eau (DCE), Fiches de synthèse. Rapport Ifremer 2005. http://www.ifremer.fr/delpc/docreference.htm.

Tyler, C. R., C. Spary, R. Gibson, E. M. Santos, J. Shears \& E. M. Hill, 2005. Accounting for differences in estrogenic responses in rainbow trout (Oncorhynchus mykiss: Salmonidae) and roach (Rutilus rutilus: Cyprinidae) exposed to effluents from wastewater treatment works. Environmental Science Technology 39: 2599-25607.

USEPA, National Recommended Water Quality Criteria, United Stated Environmental Protection Agency; 2009. http:// www.epa.gov/ost/criteria/wqctable/.

Van Aerle, R., T. M. Nolan, S. Jobling, L. B. Christiansen, J. P. Sumpter \& C. R. Tyler, 2001. Sexual disruption in a second species of wild cyprinid fish (the gudgeon, Gobio gobio) in United Kingdom freshwaters. Environmental Toxicology and Chemistry 20: 2841-2847.

Voets, J., W. Talloen, T. De Tender, S. Van Dongen, A. Covaci, R. Blust \& L. Bervoets, 2006. Microcontaminant accumulation, physiological condition and bilateral asymmetry in zebra mussels (Dreissena polymorpha) from clean and contaminated surface waters. Aquatic Toxicology 79: 213-225.

Voets, J., E. S. Redeker, R. Blust \& L. Bervoets, 2009. Differences in metal sequestration between zebra mussels from clean and polluted field locations. Aquatic Toxicology 93: 53-60.

Williams, P., M. Whitfield, J. Biggs, S. Bray, G. Fox, P. Nicolet \& D. Sear, 2003. Comparative biodiversity of rivers, streams, ditches and ponds in an agricultural landscape in Southern England. Biological Conservation 115: 329-341.

Williams, P., M. Whitfield \& J. Biggs, 2008. How can we make new ponds biodiverse? A case study monitored over 7 years. Hydrobiologia 597: 137-148.

Wingfield, J. C. \& M. Mukai, 2009. Endocrine disruption in the context of life cycles: perception and transduction of environmental cues. General Comparative Endocrinology 163: 92-96.

Wood, P. J., M. T. Greenwood \& M. D. Agnew, 2003. Pond biodiversity and habitat loss in the UK. Area 35: 206-216.

Wu, B., X. X. Zhang, X. L. Zhang, A. S. J. Yasun, Y. Zhang \& D. Y. Zhao, 2009. Semi-volatile organic compounds and trace elements in the Yangtze River source of drinking water. Ecotoxicology 84: 46-50.

Wu, B., Y. Zhang, X. X. Zhang \& S. P. Cheng, 2011. Health risk assessment of polycyclic aromatic hydrocarbons in the source water and drinking water of China: quantitative analysis based on published monitoring data. Science of the Total Environment 410-411: 112-118. 